\title{
Noise Induced Hearing Loss in Steel Factory Workers
}

\section{Abstract:}

Background: Industrial noise is usually considered mainly from the point of view of environmental health and safety, rather than nuisance, as sustained exposure can cause permanent hearing damage. Objective: To assess the Noise induced hearing loss in steel factory workers. Methods: It was a cross sectional study done to evaluate the hearing status of factory workers, working nearby a rural hospital, which were then correlated with the duration of work and SPL (in $\mathrm{dBA}$ ) of exposure at their workplace. Results: In this study, Noise Induced Hearing Loss (NIHL) was calculated in the workers by taking the average of the 4 frequencies i.e. $500 \mathrm{~Hz}, 1000 \mathrm{~Hz}, 2000 \mathrm{~Hz}$ and $4000 \mathrm{~Hz}$ in right and left ear separately. Results showed that 129 (37.83\%) workers were having Mild SNHL in Right ear i.e. between 26- $40 \mathrm{~dB}$. $203(59.54 \%)$ of the workers were having normal hearing i.e. hearing loss not exceeding $25 \mathrm{~dB}$. Only 9 (2.63\%) workers had moderate (41-60 dB) hearing loss in right ears. Whereas in case of left ears results showed that $145(42.52 \%)$ workers were having Mild SNHL in left ear i.e. between 26- $40 \mathrm{~dB} .185$ $(54.25 \%)$ of the workers were having normal hearing i.e. hearing loss not exceeding $25 \mathrm{~dB}$. Only 11 (3.23\%) workers had moderate (41-60 dB) hearing loss. Conclusion: Duration of exposure of individuals was found in the range from 6 years to 20 years. Maximum number of workers i.e. $235(68.92 \%)$ were exposed to a time duration of 16 to 20 years followed by 96 (28.15\%) who were exposed to $11-15$ years. There were 10 (2.93) workers who were having the exposure of 6 to 10 years.

Key Words: Noise Induced Hearing Loss; Occupational Hearing Loss; Industrial Noise; Factory Workers

\section{Introduction}

Noise is perhaps the most common occupational and environmental hazard but is usually not given importance. As has already said "Blindness is easy to see; deafness is invisible. Thus hearing impairment is an unseen misery".

Industrial noise is usually considered mainly from the point of view of environmental health and safety, rather than nuisance, as sustained exposure can cause permanent hearing damage. Traditionally, workplace noise has been a hazard linked to heavy industries such as steel industry and associated only with noise induced hearing loss (NIHL). Modern thinking in occupational safety and health identifies noise as hazardous to workers safety and health in many places of employment and by a variety of means. Hearing loss caused by exposure to occupational noise results in devastating disability that is virtually 100 percent preventable [1],[2]. Noise-induced hearing loss is the second most common form of sensorineural hearing deficit, after presbycusis[1] .

\section{Gaurav Agarwal, Prakash S Nagpure, Shweta V Gadge}

Mahatma Gandhi Institute of Medical Sciences, Sevagram Wardha, India

Corresponding Author:

Dr. Gaurav Agarwal

Email: gaurav.ag239@gmail.com

(c) 2014 IJOSH All rights reserved.
This study looks into the insights of Noise Induced Hearing Loss in Steel Factory Workers.

\section{Methods}

A study was conducted on the factory workers, working in steel factory nearby a rural hospital. Study was done over a period of 2 years i.e. from 1st September 2011 to 31st August 2013. All the workers included in the study were having a minimum of 5 years of noise exposure. Workers having age more than 45 years, having Presbyacusis or having conductive hearing loss i.e. Air-Bone(A-B) gap $>10 \mathrm{~dB}$ were excluded from the study.

A total of 350 factory workers were enrolled in the study. Out of which 9 were excluded as they were found to have conductive hearing loss i.e. A-B gap $>10 \mathrm{~dB}$ as per the study criteria. Sound Pressure Level (SPL) was assessed using SPL meter model no. DB 100 manufactured by KIMO Instruments, of the particular area of the factory, to which the worker was exposed was calculated. SPL meter is manufactured according to the IEC (International Electrotechnical Commission) 61672-1 Class 2 
standard specifications. It was also sound calibrated from time to time. In this study initially we went to the factory and identified the workers as per our inclusion criteria. Then the SPL to which the worker was exposed at his respective workplace was measured by SPL meter. Thereafter the informed consent was taken for study following which they were called to the ENT OPD. In the OPD all workers had undergone detailed history followed by general physical and ENT examination including Tuning Fork Tests (TFT). Then audiometry was done in the OPD and hearing loss was assessed.

\section{Results}

In this study 341 workers with age ranging from 27 to 45 years were included. SPL was calculated with the help of SPL meter $\mathrm{DB}-100$ were found to be in the range from $65 \mathrm{dBA}$ to $92 \mathrm{dBA}$. Maximum number of workers i.e. 122 (35.78\%) were exposed to 81-85 dBA, followed by $108(31.67 \%)$ workers were exposed to 86-90 dBA. There were 51 (14.96\%) workers exposed to 65-70 $\mathrm{dBA}$, followed by $36(10.55 \%)$ workers were exposed to $76-80$ dBA. $14(4.11 \%)$ and $10(2.93 \%)$ workers were exposed to 71-75 $\mathrm{dBA}$ and $>90 \mathrm{dBA}$ respectively. Both the right and left ears of all workers were exposed to similar SPL levels. SPL exposure is also shown in Table I.

Table I: Exposure of workers( Right and Left Ears) in terms of SPL (in dBA)

\begin{tabular}{|c|c|c|c|c|}
\hline SPL (dBA) & Right Ear & $\%$ & Left Ear & $\%$ \\
\hline $65-70$ & 51 & 14.96 & 51 & 14.96 \\
\hline $71-75$ & 14 & 4.11 & 14 & 10.55 \\
\hline $76-80$ & 36 & 10.55 & 36 & 35.78 \\
\hline $81-85$ & 122 & 35.78 & 122 & 31.67 \\
\hline $86-90$ & 108 & 31.67 & 108 & 2.93 \\
\hline$>90$ & 10 & 2.93 & 10 & 100 \\
\hline Total & 341 & 100 & 341 & \\
\hline
\end{tabular}

Exposure of individuals in terms of years of exposure was found in the range from 6 years to 20 years. Maximum number of workers i.e. $235(68.92 \%)$ were exposed to a time duration of 16 to 20 years followed by $96(28.15 \%)$ who were exposed to $11-15$ years. There were 10 (2.93) workers who were having the exposure of 6 to 10 years. Duration ( in years) of exposure of workers is being shown in Table II.

Predisposing factors studied for association with NIHL are SPL of exposure in terms of dBA and duration of exposure in terms of years.

$\mathrm{NIHL}$ was then calculated in the workers by taking the average of the 4 frequencies i.e. $500 \mathrm{~Hz}, 1000 \mathrm{~Hz}, 2000 \mathrm{~Hz}$ and $4000 \mathrm{~Hz}$ in right and left ear separately. Results showed that 129 (37.83\%)
Table II: Duration ( in years) of noise exposure of workers

\begin{tabular}{|c|c|c|}
\hline Duration (in years) & No. of Workers & Percentage \\
\hline $\mathbf{6 - 1 0}$ yrs & 10 & 2.93 \\
\hline $\mathbf{1 1 - 1 5}$ yrs & 96 & 28.15 \\
\hline $\mathbf{1 6 - 2 0}$ yrs & 235 & 68.92 \\
\hline Total & 341 & 100 \\
\hline Range & & \\
\hline
\end{tabular}

workers were having Mild SNHL in Right ear i.e. between 26- 40 dB. 203 (59.54\%) of the workers were having normal hearing i.e. hearing loss not exceeding $25 \mathrm{~dB}$. Only 9 (2.63\%) workers had moderate (41-60 dB) hearing loss and none of the worker were found to have severe or profound hearing loss in right ears (Table III).

Table III: Noise Induced Hearing Loss in Right Ears

\begin{tabular}{|ccc|}
\hline NIHL & No of Right ears & Percentage (\%) \\
\hline Normal (0-25) & 203 & 59.54 \\
\hline Mild (26-40) & 129 & 37.83 \\
\hline Moderate (41-60 dB) & 9 & 2.63 \\
\hline Severe (61-80 dB) & 0 & 0.00 \\
\hline Profound (>80) & 0 & 0.00 \\
\hline Total & 341 & 100.00 \\
\hline
\end{tabular}

It was shown that $145(42.52 \%)$ workers were having Mild SNHL in left ear i.e. between 26- 40 dB. 185 (54.25\%) of the workers were having normal hearing i.e. hearing loss not exceeding 25 dB. Only $11(3.23 \%)$ workers had moderate $(41-60 \mathrm{~dB})$ hearing loss and none of the worker were found to have severe or profound hearing loss in left ears (Table IV)

Table IV: Noise Induced Hearing Loss in Left Ears

\begin{tabular}{|c|c|c|}
\hline NIHL & No of left ears & Percentage(\%) \\
\hline Normal (0-25) & 185 & 54.25 \\
\hline Mild (26-40) & 145 & 42.52 \\
\hline Moderate(41-60 dB) & 11 & 3.23 \\
\hline Severe(61-80 dB) & 0 & 0.00 \\
\hline Profound(>80) & 0 & 0.00 \\
\hline Total & 341 & 100.00 \\
\hline
\end{tabular}

The hearing loss in each ear i.e. right and left of the workers were correlated with the level of SPL exposure. Maximum number of worker's right ears i.e. 122 were exposed to 81-85 dBA out of which $87(71.31 \%)$ were having the hearing in normal range and $35(28.69 \%)$ were having the hearing in mild range followed by 108 right ears which were found to be exposed to $86-90 \mathrm{dBA}$, of which $80(74.07 \%)$ were having mild hearing loss 
and $23(21.3 \%) \& 5(4.63 \%)$ were having normal and moderate range of hearing respectively. It was found that in case of right ears exposed to $65-70 \mathrm{dBA}, 50(98.04 \%)$ out of total 51 right ears were having normal hearing and only $1(1.96 \%)$ right ear of a worker was having mild hearing loss. 36 right ears were exposed to $76-80 \mathrm{dBA}$ of which $30(83.33 \%)$ were found to have normal hearing and $6(16.67 \%)$ were found to have hearing in mild category of hearing loss. $13(92.86 \%)$ right ears out of total 14 right ears exposed to 71-75 dBA were having normal hearing and $1(7.14 \%)$ was having mild hearing loss. None of the ears exposed to SPL more than 90dBA were having normal hearing, it was found that $6(60 \%)$ of right ears were having hearing loss in Mild category and $4(40 \%)$ in the moderate category. Maximum mean hearing loss was found in workers exposed to $>90 \mathrm{dBA}$ i.e. $40.50 \mathrm{~dB}$. Mean hearing loss in workers exposed to 65-70 dBA, 71-75 dBA, 76-80 dBA, 81-85 dBA and 86-90 dBA were $27.5 \mathrm{~dB}$, $26.25 \mathrm{~dB}, 28.54 \mathrm{~dB}, 28.85 \mathrm{~dB}$ and $31.52 \mathrm{~dB}$ respectively.

Chi square test was applied to know the level of significance between the SPL of exposure and hearing impairment. $-2 \times$ value was found to be 181.04 and $p$ value was found less than 0.05 . It showed the relation to be significant (Table $\mathrm{V}$ )

Table V: Correlation between the SPL of exposure and hearing impairment in right ears
$90 \mathrm{dBA}$ were having normal hearing, it was found that $6(60 \%)$ of right ears were having hearing loss in Moderate category and $3(30 \%)$ in mild category. Maximum mean hearing loss was found in workers exposed to $>90 \mathrm{dBA}$ i.e. $41.25 \mathrm{~dB}$. Mean hearing loss in workers exposed to 65-70 dBA, 71-75 dBA, 76-80 dBA, 81-85 $\mathrm{dBA}$ and 86-90 dBA were $27.18 \mathrm{~dB}, 27.5 \mathrm{~dB}, 28.39 \mathrm{~dB}, 29.47$ $\mathrm{dB}$, and $32.26 \mathrm{~dB}$ respectively.

Chi square test was applied to know the level of significance between the SPL of exposure and hearing impairment. -2xvalue was found to be 198.78 and $p$ value was found less than 0.05 making it significant (Table VI).

Duration of exposure in years was compared to the hearing impairment. Maximum number of worker's right ears i.e. 235 were exposed for 16-20 years and out of which it was found that 126 ( $59.53 \%$ ) were having normal hearing, $102(43.40 \%)$ were found to have mild hearing loss and $7(2.98 \%)$ were having moderate hearing loss. out of the 96 right ears exposed for a duration in the range of $11-15$ years, $69(71.88 \%)$ were having normal hearing and $25(26.04 \%) \& 2(2.08 \%)$ were having hearing loss in mild \& moderate range respectively. Right ears exposed to 5-10 years did not show moderate hearing loss but only mild in $2(20 \%)$ and normal in $8(80 \%)$. Mean hearing loss was found to be as $35 \mathrm{~dB}, 30.64 \mathrm{~dB}$ and $31.39 \mathrm{~dB}$ in category 5-10 years, $11-15$ years and $16-20$ years respectively $-2 x$.value

\begin{tabular}{|c|c|c|c|c|c|c|c|c|}
\hline $\begin{array}{c}\text { SPL } \\
\text { (in dBA) }\end{array}$ & No. of Right Ears & $\begin{array}{l}\text { Normal } \\
(0-25 \mathrm{~dB})\end{array}$ & $\%$ & $\begin{array}{c}\text { Mild } \\
(26-40 \mathrm{~dB})\end{array}$ & $\%$ & $\begin{array}{l}\text { Moderate } \\
\text { (41-60dB) }\end{array}$ & $\%$ & $\begin{array}{l}\text { Mean Hearing Loss (in } \\
\text { dB) }\end{array}$ \\
\hline $65-70$ & 51 & 50 & 98.04 & 1 & 1.96 & 0 & 0.00 & 27.50 \\
\hline 71-75 & 14 & 13 & 92.86 & 1 & 7.14 & 0 & 0.00 & 26.25 \\
\hline $76-80$ & 36 & 30 & 83.33 & 6 & 16.67 & 0 & 0.00 & 28.54 \\
\hline $81-85$ & 122 & 87 & 71.31 & 35 & 28.69 & 0 & 0.00 & 28.85 \\
\hline $86-90$ & 108 & 23 & 21.30 & 80 & 74.07 & 5 & 4.63 & 31.52 \\
\hline$>90$ & 10 & 0 & 0.00 & 6 & 60.00 & 4 & 40.00 & 40.50 \\
\hline Total & 341 & 203 & 59.54 & 129 & 37.83 & 9 & 2.64 & - \\
\hline \multicolumn{2}{|r|}{-2 xvalue } & \multicolumn{7}{|c|}{181.04} \\
\hline \multicolumn{2}{|r|}{$\mathrm{p}$-value } & \multicolumn{7}{|c|}{$0.000, p<0.05$} \\
\hline
\end{tabular}

The hearing loss in left ear of the workers were correlated with the level of SPL exposure. Maximum number of worker's left ears i.e. 122 were exposed to 81-85 dBA out of which $72(59.02 \%)$ were having the hearing in normal range and 50 (40.98\%) were having the hearing in mild range followed by 108 right ears which were found to be exposed to $86-90 \mathrm{dBA}$, of which $79(73.15 \%)$ were having mild hearing loss and $24(22.22 \%) \& 5(4.63 \%)$ were having normal and moderate range of hearing respectively. It was found that in case of left ears exposed to 65-70 dBA, 47 $(92.16 \%)$ out of total 51 right ears were having normal hearing and $4(7.84 \%)$ left ear of workers were having mild hearing loss. 36 right ears were exposed to $76-80 \mathrm{dBA}$ of which $29(80.56 \%)$ were found to have normal hearing and 7 (19.44\%) .

were found to have hearing in mild category of hearing loss. 12 ( $85.71 \%$ ) left ears out of total 14 left ears exposed to 71-75 dBA were having normal hearing and $2(14.29 \%)$ were having mild hearing loss. $1(10 \%)$ of the ears exposed to SPL more than was found to be 9.82 and $p$ value was 0.003 , which was found to be significant ( Table VII).

In case of left ears, maximum number of worker's left ears i.e. 235 were exposed for 16-20 years and out of which it was found that $117(49.79 \%)$ were having normal hearing, $110(46.81 \%)$ were found to have mild hearing loss and $8(3.40 \%)$ were having moderate hearing loss. out of the 96 left ears exposed for a duration in the range of $11-15$ years, $62(64.58 \%)$ were having normal hearing and $31(32.29 \%) \& 3(3.13 \%)$ were having hearing loss in mild \& moderate range respectively. Left ears exposed to $5-10$ years did not show moderate hearing loss but only mild in $4(40 \%)$ and normal in 6(60\%). Mean hearing loss was found to be as $28.75 \mathrm{~dB}, 31.21 \mathrm{~dB}$ and $31.70 \mathrm{~dB}$ in category $5-10$ years, $11-15$ years and $16-20$ years respectively -2 .value was found to be 6.55 and $p$ value was 0.161 , which was found to be non-significant ( Table VIII). 
Original Article / IJOSH/ ISSN 2091-0878

Table VI: Correlation between the SPL of exposure and hearing impairment in left ears

\begin{tabular}{|c|c|c|c|c|c|c|c|c|}
\hline $\begin{array}{c}\text { SPL } \\
\text { ( in dBA) }\end{array}$ & $\begin{array}{l}\text { No. of Left } \\
\text { Ears }\end{array}$ & $\begin{array}{l}\text { Normal } \\
(0-25 \mathrm{~dB})\end{array}$ & $\%$ & $\begin{array}{c}\text { Mild } \\
\text { (26-40 dB) }\end{array}$ & $\%$ & $\begin{array}{l}\text { Moderate } \\
(41-60 \mathrm{~dB})\end{array}$ & $\%$ & $\begin{array}{l}\text { Mean Hearing Loss } \\
\text { (dB) }\end{array}$ \\
\hline $65-70$ & 51 & 47 & 92.16 & 4 & 7.84 & 0 & 0.00 & 27.18 \\
\hline 71-75 & 14 & 12 & 85.71 & 2 & 14.29 & 0 & 0.00 & 27.50 \\
\hline $76-80$ & 36 & 29 & 80.56 & 7 & 19.44 & 0 & 0.00 & 28.39 \\
\hline $81-85$ & 122 & 72 & 59.02 & 50 & 40.98 & 0 & 0.00 & 29.47 \\
\hline $86-90$ & 108 & 24 & 22.22 & 79 & 73.15 & 5 & 4.63 & 32.26 \\
\hline$>90$ & 10 & 1 & 10.00 & 3 & 30.00 & 6 & 60.00 & 41.25 \\
\hline Total & 341 & 185 & 54.25 & 145 & 42.52 & 11 & 3.23 & - \\
\hline \multicolumn{2}{|c|}{-2 Nvalue } & \multicolumn{7}{|c|}{198.78} \\
\hline \multicolumn{2}{|c|}{$\mathrm{p}$-value } & \multicolumn{7}{|c|}{$0.000, p<0.05$} \\
\hline
\end{tabular}

Table VII: Hearing loss in right ear according to duration of years of exposure

\begin{tabular}{|c|c|c|c|c|c|c|c|c|}
\hline $\begin{array}{l}\text { Duration } \\
\text { ( in yrs) }\end{array}$ & $\begin{array}{l}\text { No. of Right } \\
\text { Ears }\end{array}$ & $\begin{array}{l}\text { Normal } \\
(0-25 \mathrm{~dB})\end{array}$ & $\%$ & $\begin{array}{c}\text { Mild } \\
(26-40 \mathrm{~dB})\end{array}$ & $\%$ & $\begin{array}{l}\text { Moderate } \\
(41-60 \mathrm{~dB})\end{array}$ & $\%$ & $\begin{array}{l}\text { Mean Hearing Loss } \\
\text { (dB) }\end{array}$ \\
\hline 5-10 yrs & 10 & 8 & 80.00 & 2 & 20.00 & 0 & 0.00 & 35.00 \\
\hline $11-15$ yrs & 96 & 69 & 71.88 & 25 & 26.04 & 2 & 2.08 & 30.64 \\
\hline $16-20$ yrs & 235 & 126 & 53.62 & 102 & 43.40 & 7 & 2.98 & 31.39 \\
\hline Total & 341 & 203 & 59.53 & 129 & 37.83 & 9 & 2.64 & - \\
\hline & & \multicolumn{7}{|c|}{9.82} \\
\hline \multicolumn{2}{|c|}{ p-value } & \multicolumn{7}{|c|}{$0.003, p>0.05$} \\
\hline
\end{tabular}

Table VIII: Hearing loss of worker's left ears according to duration of exposure in years

\begin{tabular}{|c|c|c|c|c|c|c|c|c|}
\hline $\begin{array}{l}\text { Duration } \\
\text { (in yrs) }\end{array}$ & No. of Left Ears & $\begin{array}{l}\text { Normal } \\
(0-25 \mathrm{~dB})\end{array}$ & $\%$ & $\begin{array}{l}\text { Mild } \\
\text { (26-40 dB) }\end{array}$ & $\%$ & $\begin{array}{l}\text { Moderate } \\
(41-60 \mathrm{~dB})\end{array}$ & $\%$ & $\begin{array}{l}\text { Mean Hearing Loss } \\
\text { (dB) }\end{array}$ \\
\hline $5-10 \mathrm{yrs}$ & 10 & 6 & 60.00 & 4 & 40.00 & 0 & 0.00 & 28.75 \\
\hline $11-15$ yrs & 96 & 62 & 64.58 & 31 & 32.29 & 3 & 3.13 & 31.21 \\
\hline $16-20 \mathrm{yrs}$ & 235 & 117 & 49.79 & 110 & 46.81 & 8 & 3.40 & 31.70 \\
\hline Total & 341 & 185 & 54.25 & 145 & 42.52 & 11 & 3.23 & - \\
\hline \multicolumn{2}{|c|}{-2 xvalue } & \multicolumn{7}{|c|}{6.55} \\
\hline \multicolumn{2}{|c|}{$\mathrm{p}$-value } & \multicolumn{7}{|c|}{$0.161, p>0.05$} \\
\hline
\end{tabular}


After getting all these results, now to obtain a correlation and level of significance between NIHL in right and left ears to age of worker in years, Duration of exposure in years and SPL of exposure in dBA. we applied multiple logistic regression method. We found for age and NIHL in right ear, Odd's Ratio as 0.140 , unpaired t test value as 1.73 and $p$-value as 0.083 which was statistically not significant. For duration of exposure and $\mathrm{NIHL}$ in right ear, Odd's ratio was 0.231 , unpaired $t$ test value was 2.87 and $p$-value was 0.004 which was statistically significant. For SPL and NIHL in right ear Odd's ratio was 0.655 , unpaired t test value as 15.79 and $p$-value as 0.00 which was statistically significant. Results proved that there is maximum association between SPL of exposure and NIHL followed by duration of exposure and NIHL ( Table IX) .

Table IX: Multiple Logistic Regression for NIHL in Worker's Right Ears and age, duration and SPL

\begin{tabular}{|c|c|c|c|c|c|}
\hline & \multicolumn{2}{|c|}{$\begin{array}{l}\text { Unstandardized } \\
\text { Coefficients }\end{array}$} & \multirow{2}{*}{$\begin{array}{l}\text { Odd's } \\
\text { Ratio }\end{array}$} & \multirow{2}{*}{$t$ test } & \multirow{2}{*}{ p-value } \\
\hline & B & Std. Error & & & \\
\hline NIHL Right Ear & -18.03 & 4.66 & - & - & - \\
\hline Age(yrs) & -0.27 & 0.15 & 0.140 & 1.73 & $\begin{array}{c}0.083 \\
p>0.05\end{array}$ \\
\hline $\begin{array}{l}\text { Duration of exposure } \\
\text { (yrs) }\end{array}$ & 0.51 & 0.17 & 0.231 & 2.87 & $\begin{array}{c}0.004 \\
p<0.05\end{array}$ \\
\hline SPL (dBA) & 0.56 & 0.03 & 0.655 & 15.79 & $\begin{array}{c}0.000 \\
p<0.05\end{array}$ \\
\hline
\end{tabular}

Whereas in case of left ears, we found that, for age and NIHL in left ear, Odd's Ratio as 0.028 , unpaired $t$ test value as 0.330 and $\mathrm{p}$-value as 0.742 which was statistically not significant. For duration of exposure and NIHL in right ear, Odd's ratio was 0.134 , unpaired t test value was 1.576 and $p$-value was 0.116 which was statistically not significant. For SPL and NIHL in right ear Odd's ratio was 0.592, unpaired $t$ test value as 13.466 and $p$ value as 0.00 which was statistically significant. Results proved that there is maximum association between SPL of exposure and NIHL. ( Table X).

Table X: Multiple Logistic Regression for NIHL in Worker's Left Ears and age, duration and SPL

\begin{tabular}{|c|c|c|c|c|c|}
\hline & \multicolumn{2}{|c|}{$\begin{array}{l}\text { Unstandardized } \\
\text { Coefficients }\end{array}$} & \multirow{2}{*}{$\begin{array}{l}\text { Odd's } \\
\text { Ratio }\end{array}$} & \multirow[t]{2}{*}{$\mathrm{t}$ - test } & \multirow{2}{*}{$p$-value } \\
\hline & B & Std. Error & & & \\
\hline NIHL Left Ear & -20.02 & 5.13 & & - & - \\
\hline Age (yrs) & -0.05 & 0.17 & 0.028 & 0.330 & $0.742 p>0.05$ \\
\hline $\begin{array}{c}\text { Duration of exposure } \\
\text { (yrs) }\end{array}$ & 0.31 & 0.19 & 0.134 & 1.576 & $0.116 p>0.05$ \\
\hline SPL (dBA) & 0.52 & 0.03 & 0.592 & 13.466 & $0.000 p<0.05$ \\
\hline
\end{tabular}

This clearly shows that NIHL is more significantly associated with SPL of exposure (noise at workplace) and then duration of exposure rather than the age of the worker.

\section{Discussion}

Noise-Induced Hearing Loss (NIHL) is still a major source of health problem in industrial workers due to continuous exposure to high frequency sounds emitting from the machines. Noise is any unwanted sound that at low intensity may be irritating and at high intensity may damage hearing. The current study found that exposure to occupational noise was significantly associated with increased hearing thresholds as was shown in many international reports ( Agrawal et al., 2010; Amedofu,2002; Scott et al., 2004; Uddin et al, 2006; Nelson et al., 2005; Dobie, 2008).[3],[4],[5],[6],[7],[8]. Present study showed that 129 $(37.83 \%)$ workers were having mild SNHL in Right ears and 9 $(2.63 \%)$ workers had moderate $(41-60 \mathrm{~dB})$ hearing loss. Whereas in case of left ears results showed that $145(42.52 \%)$ workers were having mild SNHL in left ear and Only 11 (3.23\%) workers had moderate (41-60 dB) hearing loss and none of the worker was found to have severe or profound hearing loss, i.e. NIHL was $40.46 \%$ in right ear and $45.75 \%$ in left ears. Compared to other authors, Hendarmin (1971)[9] got $50 \%$ NIHL on workers in ice and manufacturing plant factory in Jakarta. In a study in Brazil in 1997 by Morata et al.[10] explored the effects of occupational exposure to solvents and noise on the hearing of rotogravure printing workers found $49 \%$ of the workers had hearing loss. A study in Cairo by Moselhi[11] in 1979 was done on 114 workers showed impairment of hearing among only $9.6 \%$. Occupational noise is a significant cause of adult-onset hearing loss. Our study is also in corroboration with other studies that had found that exposure to occupational noise was significantly associated with increased hearing thresholds. (Agrawal et al., 2010; Uddin et al., 2006; Dobie, 2008)[3],[6],[8]. Shearing forces caused by any sound have an impact on the stereocilia of the hair cells of the basilar membrane of the cochlea; when excessive, these forces can cause cell death. Avoiding noise exposure stops further progression of the damage. In our study, maximum number of worker's right ears i.e. 122 were exposed to $81-85$ dBA out of which $87(71.31 \%)$ were having the hearing in normal range and 35 (28.69\%) were having the hearing in mild hearing loss range. Maximum number of worker's left ears i.e. 122 were exposed to 81-85 dBA out of which $72(59.02 \%)$ were having the hearing in normal range and 50 (40.98\%) were having mild hearing loss. In a study by Raja and Ganguly[12] in 1983 on Heavy engineering industry workers showed, 14-40 dB in 53 workers on machine shop exposed to 83-92 dBA; $19-70 \mathrm{~dB}$ in 60 workers in press division exposed to $94-110 \mathrm{dBA}$. Chan et al.[13](1990) reported NIHL ratio $26.3 \%$ on the subjects exposed noise level between 87 and $98 \mathrm{~dB}(\mathrm{~A})$. A study by Ertem et al.[14] in 1996 on noise Induced Hearing Loss among Cotton Textile and Carpet Mill Workers in Diyarbakır-Turkey showed that $30 \%$ workers exposed to 65 to $80 \mathrm{dBA}$ developed hearing loss. NIHL increased as the SPL levels increased. In case of 81-85 dBA SPL and $>90$ dBA SPL, $57.14 \%$ and $63.25 \%$ workers developed hearing loss. Harmadji et al.[15], 2004 did a study on steel factory workers. He found that if workers were exposed to $>90$ 
dBA SPL $84 \%$ workers developed hearing loss. When duration of exposure in years was compared to the hearing impairment. Results were found to be in comparison with other authors. A study by Oleru[16] et al. in 1990 on the workers in a car factory exposed to 94-104 dB showed hearing thresholds of 165 workers were significantly higher than nonexposed controls and correlated significantly with duration of employment. Hiayat[17] et al. in 1991 reported incidence of NIHL on workers of textile factory in Malang $17.20 \%$ with 10 years working period and 46 $\%$ with 15 years working period. In a study on workers of textile factory by Suheryanto et al.[18] in 1994 reported $44.44 \%$ with $5-9$ years working period, $66.67 \%$ with 10 - 14 years and $85.91 \%$ with 15 - 19 years. In the present study, mean hearing loss in right ear of factory worker's was found to be as $35 \mathrm{~dB}$, $30.64 \mathrm{~dB}$ and $31.39 \mathrm{~dB}$ in category $5-10$ years, $11-15$ years and 16-20 years respectively. Whereas in case of left ears mean hearing loss was found to be as $28.75 \mathrm{~dB}, 31.21 \mathrm{~dB}$ and 31.70 $\mathrm{dB}$ in category 5-10 years, 11-15 years and 16-20 years respectively. In a study by Ertem et al.[14] in 1996 they found that mean hearing loss in right ear of cotton textile and carpet mill worker's was found to be as $29.07 \mathrm{~dB}, 33.41 \mathrm{~dB}$ and 33.77 $\mathrm{dB}$ in category 5-10 years, 11-15 years and 16-20 years respectively. Another study by Damon Ketabi et al.[19] in 2010 found the mean hearing loss on factory workers to be 37 and 56 in 11-15 years and 16-20 years group of exposure to noise. As a matter of fact, we know that NIHL (permanent threshold shift) is only preventable and not curable. Hence, regular medical examinations of workers in all industries is necessary. It is also needed to use personal protective equipments and to provide appropriate medical education of both workers and the management staff of said industries in order to prevent this kind of occupational disease (NIHL). In our study, we came across that most common excuses reported by workers for not wearing hearing protectors include discomfort, interference with hearing speech and warning signals and the belief of workers that there is no control over an inevitable process that causes hearing loss. Given adequate education and training, workers can realize the crucial importance of wearing hearing protectors. Educational methods and materials should be tailored to the specific audience. The goal of education and training is not just to inform, but also to motivate. The success or failure of a hearing loss prevention program, including employee buy-in, depends upon effective education and training (Berger[20], 2001). Health education is the need of the hour.

\section{Conclusion}

When hearing loss is suspected, a thorough history, physical examination and audiometry should be performed. If these examinations disclose evidence of hearing loss, full audio logic evaluation is recommended. Though there are a number of legislations made to prevent this type of hearing loss. Many of these legislations have also been adopted and formulated by the higher authorities, but still there are lacunae. There is a need to understand this agony of a factory worker who gets this hearing loss as a reward for his services in factories. There is a need to motivate and educate the workers and they should know that their hearing is in their hands which is virtually 100 per cent preventable[1],[2].
Noise-induced hearing loss can be prevented by avoiding excessive noise, educating the workers and keep them motivated for using hearing protection such as earplugs and earmuffs.

\section{References}

1. Rabinowitz PM. Noise induced hearing loss, Am Fam physician. 2000 May $1 ; 61(9): 2749-2756$.

2. Ian Gillespie. Noise-induced hearing loss: A preventable condition. BCMJ, 2011 April; 53(3) p- President's Comment.

3. Agrawal Y, Niparko JK, Dobie RA. Estimating the effect of occupational noise exposure on hearing thresholds: the importance of adjusting for confounding variables. Ear \& Hearing. 2010 Apr;31(2):234-7.

4. Amedofu GK. Hearing-impairment among workers in a surface gold mining company in Ghana. Afr J Health Sci. 2002 Jan-Jun;9(12):91-7.

5. Scott DF, Grayson RL, Metz EA. Disease and illness in U.S. mining, 1983-2001. Journal of occupational and environmental medicine / American College of Occupational and Environmental Medicine. 2004 Dec;46(12):1272-7.

6. Uddin JF, Dingle AF, Sharp JF \& Flood LM. Occupational hearing loss in the United Kingdom. In: Sataloff RT \& Sataloff $\mathrm{J}$ (eds.) Occupational Hearing Loss. 3rd ed. New York: CRC publishers; 2006. p859-870.

7. Nelson DI, Nelson RY, Concha-Barrientos M, Fingerhut M. The global burden of occupational noise-induced hearing loss. American journal of industrial medicine. 2005 Dec;48(6):446-58.

8. Dobie RA. The burdens of age-related and occupational noise-induced hearing loss in the United States. Ear and hearing. 2008;29(4):565-77.

9. Hendarmin $\mathrm{H}$. Noise induce hearing loss. In: Pandi PS (ed). Kumpulan naskah Konas II Perhati Buku I , Jakarta. 1971; p224 - 8.

10. Morata TC, Fiorini AC, Fischer FM, Colacioppo S, Wallingford KM, Krieg EF, et al. Toluene-induced hearing loss among rotogravure printing workers. Scand J Work Environ Health. 1997 Aug;23(4):289-98.

11. Moselhi M, El-Sadik YM, El-Dakhakhny A. A six-year follow up study for evaluation of the $85 \mathrm{dBA}$ safe criterion for noise exposure. Am Ind Hyg Assoc J. 1979 May;40(5):424-6.

12. Raja S, Ganguly T. Impact of exposure to noise on the hearing acuity of employees in a heavy engineering industry. The Indian Journal of Medical Research. 1983 Jul;78:100-13.

13. Chan OY, Lee CS, Tan KT, Thirumoorthy T. Health problems among spice grinders. Journal of Social Occupational Medicine. 1990 Autumn; 40(3):111-5.

14. Ertem M, Ersen I, Meric F. Noise Induced Hearing Loss Among Cotton Textile and Carpet Mill Workers. Turkish Journal of Medical Sciences. 1998;28:561-5.

15. Harmadji $\mathrm{S}$, Kabullah $\mathrm{H}$. Noise induced hearing loss in steel factory workers. Folia Medica Indonesiana. 2004;40(4):171-4.

16. Oleru UG, ljaduola GT, Sowho EE. Hearing thresholds in an auto assembly plant: prospects for hearing conservation in an Nigerian factory. Int Arch Occup Environ Health. 1990;62(3):199-202.

17. Hidayat W, Suhardono, Rasyid R, Haryuti, Choiriyah. Occupational disease through epidemiological approach. Research health problems due to noise on spinning and weaving units in the textile mills of PT X Malang 1990. Center for Research and Development of Health Services Ministry of Health. Body of research and development. surabaya [Penyakit akibat kerja melalui pendekatan epidemiologi. Penelitian gangguan kesehatan akibat kebisingan pada unit pintal dan tenun di pabrik tekstil PT X Kabupaten Malang 1990. Pusat Penelitian dan Pengembangan Pelayanan kesehatan Departemen Kesehatan RI . Badan penelitian dan pengembangan. Surabaya]. $1991: 1-5$.

18. Suheryanto R. Effect of noise on hearing machinery textile mill employees. Works to gain expertise diploma Medicine Otolaryngology Faculty of Medicine, Airlangga University / Hospital. [Pengaruh kebisingan mesin pabrik textil terhadap pendengaran karyawan. Karya untuk memperoleh ijazah keahlian IImu Penyakit THT Fakultas Kedokteran Unair/RSUD] Dr. Soetomo Surabaya. 1994.

19. Ketabi D. Noise Induced Hearing Loss among Workers of an Iranian Axial Parts Factory, 2009. International Journal of Occupational Hygiene. 2010;2(2):75-79.

20. Berger E. The ardent hearing conservationist. Spectrum Suppl. 2001;1 (18):17-8. 
method, it was found that the both forward bending and squatting postures of potato harvesting have been categorized as very high risk. The results of the posture analysis by QEC method indicated that the risk levels were high in back, shoulder/arm and neck regions and moderate in the wrist/hand regions while performing potato harvesting job in forward bending posture. While performing potato harvesting job in squat sitting posture the risk levels were high in back, wrist/hand and neck regions and moderate in shoulder/arm regions.

\section{Discussion}

The workers were habituated in different awaked postures while performing different jobs of potato cultivation. The change of posture was a common factor during dynamic work and in long term working condition. The cultivators were compelled to adopt in different awkward postures for prolonged periods of time while performing different potato cultivation jobs. Although awkward postures were most prevalent in the jobs, it was also noted that there were a lot of non-ergonomic postures of certain parts of the body which may be the possible contributing causes of pain in different body segments. A good posture becomes even more important when forceful tasks are performed. Posture is as important for the performance of tasks as it is for promoting health and minimizing stress and discomfort during work [18]. Thus, assessment of work postures is one of the starting points to address the problem of work-related body pain. There are many practical methods for evaluating postural workload based on a postural classification [19-20]. The direct observation method was proved to be a good method for studying the work postures in agricultural and other work when involved in whole body work requiring moving. The validity of visual observation to assess posture in a laboratory-simulated material-handling task [21] was established. Thus the direct observation method was used for the analysis of posture and it was noted that the forward bending posture was the dominant posture in potato cultivation jobs. The workers engaged in tunneling jobs were compelled to adopt forward bending posture throughout the work time. In case of potato plantation and potato harvesting jobs the workers were also spend maximum time in forward bending posture. The workers were found to twist and bend their body frequently during potato plantation and potato harvesting jobs. The prolonged forward bending posture imposes a high static muscular load, particularly in the trunk region. So, forward bending posture in different phases of potato cultivation jobs was generally stressful to the musculoskeletal structures, including the vertebral column. This is consistent with the past studies that have shown that forward bending and twisting of the back impose higher postural strain than the straight back postures which are important risk factors for origin of discomfort [22-24]. Meyers et al. [25] showed the relation between stressful work postures and functional disturbance of pain in various parts of the musculoskeletal system. The workers usually required moving forward (sometimes sideways) under squat posture and such movements were strenuous and cumbersome.

The work-rest cycle is dichotomized into work and rest periods. The human body shows a rhythmic balance between energy consumption and energy replacement during work and rest peri- ods. This dual process is an integral part of the operation of muscles, of the heart and if we take all the biological functions into account of the organism as a whole. Work rest is, therefore, indispensable as a physiological requirement if performance and efficiency are to be maintained.

From the studies of work-rest patterns of the potato cultivators, it has been found that total duration of work shift was high (approximately 9 hours) in all jobs of potato cultivation. Thus the prolonged tasks performed in awkward posture (bend posture) may be possible causes of pain at different segments of the workers. Al-Rahamneh et al. [26] also point out in their studies that prolonged tasks have been positively associated with body part discomfort. According to Caicoyal and Delclos [27], those performing highly repetitive tasks for longer duration reported pain at different segments of their body.

Study of MSD and body discomfort revealed that the incidence of MSDs or pain was comparatively higher in tunneling job than that the workers engaged in potato plantation and potato harvesting jobs. However, lower back problem was found extremely prevalent in all types of job of potato cultivation. It was the highest in potato harvesting (98.08\%) followed by tunneling job $(96.67 \%)$ and potato plantation operation (84.31\%). Upper back problem was also prevalent in all types of tasks of potato cultivation. It was the highest in tunneling job $(75.0 \%)$ followed by potato harvesting $(73.08 \%)$ and seed plantation operation $(41.18 \%)$. Usually the workers of different potato cultivation jobs, adopt forward bending posture with frequent postural change and sometimes twisting posture also. Highest degree of pain / discomfort was observed in lumber region of the workers of all categories. This problem might be attributed to the prolonged forward bending and twisting postures with frequent postural change. Kothiyal and Yuen, [24]; Olendorf and Drury, [28] and Reneman et al. [29] strongly pointed that forward bending and twisting posture imposes higher postural strain among the workers which might be the cause of discomfort in different body parts $[23,30]$. Osborne et al. [31] studied on farmers and reported that lower back pain was the most common MSD among the farmers, followed by upper and then lower extremity MSDs. They also suggested that the prevalence of MSDs in farmers was greater than in non-farmer populations. Long term adoption of forward bending and twist posture was associated with postural stress. Investigation suggested that bending and twisting of back awkwardly and working in the same position were both significantly associated with prevalence of lower back problem $[9,32-34]$ and both were judged by workers to be the most problematic job factors contributing to pain and injury. Goldsheyder et al. [35] reported that there was a significant association of awkward postures with back pain and the prevalence of lower back problems was significantly increased with work tasks described as "bending or twisting back in an awkward way". Das and Gangopadhyay [3] studied on potato cultivators and reported that prolonged work activity, high repetitiveness and remaining constantly in an awkward posture for a prolonged period of time may lead to MSDs.

According to the report of NIOSH [36], the kneeling, squatting and non-neutral trunk postures are the awkward posture, which are responsible for lower back disorder. The National Research 
Council (NRC) and Institute of Medicine [37] also reported that there is a clear relationship between back disorders and physical load. The lower back pain (LBP) was commonly associated with decrease muscular strength, spinal flexibility, incapacity and eventually activity limitation due to sick leave and corresponding high costs to the society, which also reported by Van Tulder et al. [38].

The higher prevalence of work related MSD at different segments of the body of the workers might be due to use of significant force, repetitive movements and longer duration of exposure [23]. A constant repetition of movements imposes a cumulative work load which can cause pain and weakness and impaired function of the muscles and other soft tissues [39]. The physiologic problems that arise from repetitive work or overuse of certain muscles, tendons and soft-tissue structures have been addressed in terms of muscle fatigue, tissue density changes, and tissue strain [40]. Physiologic evidence shows that the rate and degree of tissue damage depends on the amount of force, repetition and duration of exposure [41]. The results also indicated that MSDs was prevalent in different parts of upper limbs. It was also revealed that most of the workers of three different potato cultivation tasks reported disorders in wrist and shoulder. Wrist problem was highest in potato plantation operation $(66.67 \%)$ followed by potato harvesting $(65.38 \%)$ and tunneling job (50.0\%). However, Disorder in the shoulder was highest in tunneling job (63.33\%) followed by potato harvesting $(51.92 \%)$ and seed plantation operation $(23.53 \%)$. All these potato cultivation tasks required frequent movement of the shoulder, but the frequency of movement was very high in case of tunneling job due to spade operation. In case potato harvesting job, they collect potato and load the collected potato in a basket and the workers had to lift the loaded basket to the head of the carrier in a regular interval. Thus the frequency of upper arm movement was very high and this might be the reason for the occurrence of shoulder pain of the workers. This may evoke shoulder muscular tenderness disorder. This is due to the static fatigue of the Trapezius muscle and multifactorial identification, including static and awkward posture and work practices [42]. In all those potato cultivation tasks, major percentages of workers were affected bilaterally. This might be due to the fact that in all operations the workers were using both right and left arms almost equally during performing the job.

The occurrence of MSDs exhibited variation in the subjects of different work experienced groups. The occurrence of MSDs was higher in the subjects of Gr.-A and Gr.-C than the Gr.-B. The higher prevalence of MSD in the workers of $\mathrm{Gr}$. -A might be due to lesser experience and skill. As the workers were newly recruited they were untrained and possessed a little knowledge to operate the hand tools. From the study of the Häkkänen et al. [43] it has been revealed that among trailer assembly workers a higher rate of sick leave due to disorders of the upper limbs was found for new workers compared with experienced ones. The higher incidence of MSDs in the workers of Gr.-C might be due to reduced muscle strength and endurance with the advancement of age [44]. Alexopoulos et al. [45]; Guo et al [46] and Habib et al.
[47] noted in their studies that MSDs was significantly increased with age.

The potato cultivators were compelled to adopt in different awkward postures for prolonged period while performing different jobs of potato cultivation. Ergonomic assessment of work postures is one of the starting points to address the problem of work related body pain. Researcher proposed different methods for ergonomic assessment of working posture and quantification of ergonomic risk factors. In the present study, different postures adopted by the cultivators while performing different tasks of potato cultivation were analyzed by OWAS, REBA and QEC methods. From the results of posture analysis of three jobs of potato cultivation, it was revealed that all postures adopted by the workers during potato cultivation jobs has been categorized as moderate to very high risk and this posture was needed corrective measure immediately.

According to the different posture analysis methods, the postures adopted by the male cultivators have been categorized as having 'moderate' to 'very high' risk levels in different tasks of potato cultivation. The workers suffered account of health problems, perhaps because of prolonged working hours, awkward posture and used less safety measures while working. The prevalence of MSDs also exhibited variation in the subjects having different work experience. Moreover, ergonomic interventions such as modifying work-rest schedules would improve the work conditions and postures of the male cultivators and reduce their MSDs. From this study it has been recommended that workers should avoid awkward work postures as far as possible and take adequate rest during their work for reducing job related health hazards. The strenuous posture is one of the major problems in potato cultivation jobs. This problem may be solved by devising new equipment, which can relieve them from adopting harmful bend postures. Avoiding loads during acute pain and performing some special types of exercises can reduce the low back pain. Awareness and training programs about the correct work posture, personal protective devices and using proper work methods among the cultivators may be another solution of the problem.

\section{References}

1. Census of India 2011. http://www.censusindia.gov.in

2. Gangopadhyay S, Das B, Das T, Ghoshal G. An ergonomic study on posture-related discomfort among preadolescent agricultural workers of West Bengal, India. International Journal of Occupational Safety and Ergonomics 2005, 11 (3): 315-322.

3. Das B, Gangopadhyay S. Prevalence of musculoskeletal disorders and physiological stress among adult male potato cultivators of West Bengal, India. Asia Pac J Public Health 2012. Jan 13. PMID: 22247108 [in press]

4. Sabharwal K and Kaushik S. Inter gender occupational health problems in Paddy cultivation. J Dairying Foods and HS 2011, 30(1): 43- 47. 
5. Das B, Gangopadhyay S. An ergonomics evaluation of posture related discomfort and occupational health problems among rice farmers. Occupational Ergonomics 2011, 10(12): 25-38.

6. Kar SK, Sau SK, Ahmed QR, Dhara PC. Ergonomic evaluation of work-rest pattern and work component of different rice cultivation tasks. The Indian Journal of Bio Research 2010, 79(3): 243-254.

7. Nag PK and Nag A. Drudgery, accidents and injuries in Indian agriculture. Industrial Health 2004, 42:149-162.

8. Kar SK and Dhara PC. An evaluation of musculoskeletal disorder and socioeconomic status of farmers in West Bengal, India. Nepal Medical College Journal 2007, 9(4): 245249.

9. Goswami S, Pal A, Dhara PC. Evaluation of work related musculoskeletal disorder and postural stress among female cultivators engaged in post harvesting tasks, Indian Journal of Biological Science 2012, 18:16-25.

10. Ermakova SV, Podstavkina TP, Strokina AN. Anthropometric atlas, recommendation on methods. Amerind Publishing Co. Pvt. Ltd., New Delhi. 1985.

11. Wilson JR and Corlette EN. Evaluation of human work a practical ergonomics methodology. Taylor and Francis, London. 1985.

12. Kuorinka I, Jonson B, Kilbom A, Vinterberg H, BieringSorenson F, Anderson G, et al. Standardized Nordic questionnaire for the analysis of musculoskeletal symptoms. Applied Ergonomics 1987, 18: 233-237.

13. Jacquelin LR, Drury G, Richard LB. A field methodology for the control of musculoskeletal injuries. Applied Ergonomics 1994, 25:3-16.

14. Kee D and Karwowski W. A Comparison of Three Observational Techniques for Assessing Postural Loads in Industry. International Journal of Occupational Safety and Ergonomics 2007, 13(1): 3-14.

15. Heinsalmi $P$. Method to measure working posture loads at working sites (OWAS). In: The Ergonomics of Working Postures. Corlette, Wilson and Manenica (Ed). Taylor and Francis, London. 1986, 100-104.

16. Hignett $S$ and McAtamney L. Rapid Entire Body Assessment (REBA). Applied Ergonomics 2000, 31: 201-205.

17. Li G and Buckle P. Evaluating change in exposure to risk for musculoskeletal disorders - a practical tool. Suffolk, HSE Books CRR251. 1999.

18. Corlett EN. Pain, posture and performance. In: E.N. Corlett and J. Richardson (eds), Stress, Work Design and productivity, Wiley, London. 1981, pp 1-8.

19. Mc Atamney L and Corlett EN. RULA: a survey method for the investigation of work related upper limb disorder. Applied Ergonomics 1993, 24(2): 91-99.

20. Keyserling WM. Postural analysis of the trunk and shoulders in simulated real time. Ergonomics 1986, 29:569-583.

21. Looze MP, Toussaint de, Ensink HM, Mangnus J, Beek C, Vander AJ. The validity of visual observation to assess posture in a laboratory-simulated, material handling task. Ergonomics 1994, 37:1335-1343.

22. Drake JD and Callaghan JP. Do flexion/extension postures affect the in vivo passive lumbar spine response to applied axial twist moments? Clin Biomech (Bristol, Avon) 2008, 23 (5): 510-9.

23. Chaffin DB, Andersson GBJ, Martin BJ. Occupational Biomechanics, fourth edition, Wiley-Interscience, New York. 2006.

24. Kothiyal $K$ and Yuen TW. Muscle strain and perceived exertion in patient handling with and without a transferring aid. Occupational Ergonomics 2004, 4(3): 185-197.

25. Meyers JM, Miles JA, Faucett J, Janowitz I, Tejeda DG, Weber $\mathrm{E}$, et al. Priority risk factors for back injury in agricultural field work: vineyard Ergonomics. Journal of Agromedicine 2001, 8: 37-52.

26. Al-Rahamneh HQ, Faulkner JA, Byrne C, Eston RG. Relationship between perceived exertion and physiologic markers during arm exercise with able-bodied participants and participants with poliomyelitis. Arch Phys Med Rehabil 2010, 91(2): 273-7.

27. Caicoyal M and Delclos GL. Work demands and musculoskeletal disorders from the Spanish National Survey. Occupational Medicine 2010, 60: 447-450.

28. Olendorf MR and Drury CG. Postural discomfort and perceived exertion in standardized box-holding postures. Ergonomics 2001, 44(15):1341-1367.

29. Reneman MF, Bults MMWE, Engbers LH, Mulders KKG, Göeken LNH. Measuring Maximum Holding Times and Perception of Static Elevated Work and Forward Bending in Healthy Young Adults. Journal of Occupational Rehabilitation 2001, 11(2): 87-97.

30. Granata KP and Marras WS. Relation between spinal load factors and the high-risk probability of occupational lowback disorder. Ergonomics 1999, 42:1187-1199.

31. Osborne A, Blaken C, Fullen BM, Meredith D, Phelan J, Mc Namara J, et al. Prevalence of musculoskeletal disorders among farmers: A systematic review. Am J Ind Med 2012, 55(2):143-158.

32. Roffey DM, Wai EK, Bishop P, Kwon BKS. Dagenais. Causal assessment of awkward occupational postures and low back pain: results of a systematic review. Spine 2010, 10(1): 89-99.

33. Merlino LA, Rosecrance JC, Anton D, Cook TM. Symptoms of musculoskeletal disorders among apprentice construction workers. Appl Occup Environ Hyg 2003, 18(1):57-64.

34. Pal A, De S, Sengupta P, Maity P, Dhara PC. Evaluation of work related musculoskeletal disorder and postural stress among female potato cultivators in West Bengal, India. Ergonomice SA 2015. (In sprees) 


\section{Original Article / IJOSH/ ISSN 2091-0878}

35. Goldsheyder D, Nordin M, Schecter S, Hiebert WR. Musculoskeletal symptom survey among mason tenders. Am J Ind Med 2002, 42: 384-396.

36. NIOSH. Musculoskeletal disorders and workplace factors: A critical review of epidemiologic evidence for work-related musculoskeletal disorders of the neck, upper extremity, and low back. Publication No. 97-141, 1997. Cincinnati: DHHS $\mathrm{NIOSH}$.

37. NRC and Institute of Medicine. Musculoskeletal Disorders and the Workplace: Low Back and Upper Extremities, In P. o. M. D. a. t. Workplace., (Ed.) Commission on Behavioral and Social Sciences and Education. National Academy Press; Washington, D.C. 2001.

38. Van Tulder MW, Koes BW, Bouter LM. A cost-of-illness study of back pain in the Netherlands. Pain 1995, 62:23340.

39. Gangopadhyay S, Ghosh T, Das T, Ghoshal G, Das BB. Prevalence of upper limb musculoskeletal disorders among brass metal workers in West Bengal, India. Industrial Health 2007, 45:365-370.

40. Valachi B and Valachi K. Mechanisms leading to musculoskeletal disorders in dentistry. J Am Dent Assoc 2003, 134 (10):1344-1350.

41. Geronilla KB, Miller GR, Mowrey KF, Wu JZ, Kashon ML, Brumbaugh K. et al. Dynamic force responses of skeletal muscle during stretch shortening cycle. Euro J Appl Physiol 2003, 90(1-2):144-153.

42. Hayes M, Cockrell D, Smith DR. A systematic review of musculoskeletal disorders among dental professionals. Int J Dent Hyg 2009, 7(3):159-65.

43. Häkkänen M, Viikari-Juntura E and Martikainen R. Job experience, work load, and risk of musculoskeletal disorders. Occup Environ Med 2001, 58:129-135.

44. Holmström E and Engholm G. Musculoskeletal disorders in relation to age and occupation in Swedish construction workers. Am J Ind Med 2003, 44(4):377-384.

45. Alexopoulos EC, Burdorf A, Kalokerinou A. Risk factors for musculoskeletal disorders among nursing personnel in Greek hospitals. International Archives of Occupational and Environmental Health 2003,76(4):289-294.

46. Guo HR, Chang YC, Yeh WY, Chen CW, Guo YL. Prevalence of musculoskeletal disorder among workers in Taiwan: A nationwide study. Journal of Occupational Health 2004, 46 (1): 26-36.

47. Habib RR, Hamdan M, Nuwayhid I, Odaymat F. Musculoskeletal Disorders among Full-Time Homemakers in Poor Communities. Women Health 2005, 42(2): 1-14. 